\title{
Living standards and mortality in the European Community
}

\author{
J P Mackenbach, C W N Looman
}

\begin{abstract}
Objective - The association between living standards and mortality in the European Community (EC) was investigated using regional level data from all EC member countries.

Data and methods - Data covering the 1980 s were extracted from various publications. Data on "all cause" mortality (standardised mortality ratios, both sexes, all ages), living standards (gross domestic product, car access, unemployment rates), and some potential confounders (population density, agricultural employment, industrial employment, country) were available for 133 regions. Multiple regression analysis was used for each living standard variable, taking InSMR as the dependent variable. Results - It is only after taking into account potential confounders that higher living standards are associated with lower mortality. Unemployment rates have the strongest association - each additional percentage in unemployment in the regional population is associated with an increase in mortality by $0.81 \%$. There is important variation between countries in the living standardsmortality relationship. The latter ranges from relatively strong in the UK to absent in Italy.
\end{abstract}

Discussion - The results of this study show that there is an association between living standards and mortality at the regional level in the EC, but that this association comes to light only after controlling for confounding variables. It seems that the mortality increasing effects of urbanisation and industrialisation have obscured the mortality lowering effects of high living standards. In addition, factors specific to countries (such as dietary habits) act as confounders. The latter finding is interpreted in the light of differences between countries in the way in which they have gone through the "epidemiologic translation" from infectious diseases to the "western" diseases that currently dominate the mortality pattern.

\section{(f Epidemiol Community Health 1994;48:140-145)}

It is well known that socioeconomic factors are important determinants of health. In many countries, studies of individuals have shown that mortality and morbidity are higher in those with lower socioeconomic status. ${ }^{12}$ While this is also true for those countries of the European Community (EC) for which such data are available, ${ }^{3-10}$ at the national level there is no association at all between living standards and mortality (table 1). The correlation coefficients between gross domestic product (GDP) on the one hand and life expectancy and "all cause" mortality rates on the other are both close to zero. Greece and Portugal, for example, both have low GDPs, but Greece has a low and Portugal a high mortality rate.

We have tried to explain this apparent anomaly by undertaking more detailed analysis of the association between living standards and mortality in the EC. Our hypothesis was that one or more confounding factors (for example,

Table 1 A comparison of gross domestic product (GDP) and several indicators of mortality in the EC

\begin{tabular}{|c|c|c|c|c|c|}
\hline \multirow[b]{2}{*}{ Country } & \multirow[b]{2}{*}{$G D P^{*}$} & \multirow{2}{*}{$\begin{array}{l}\text { Life } \\
\text { expectancy } \\
\text { at birth }{ }^{\dagger}\end{array}$} & \multicolumn{3}{|c|}{ Age standardised mortality } \\
\hline & & & $\begin{array}{l}\text { All } \\
\text { causes }\end{array}$ & Neoplasms & $\begin{array}{l}\text { Cardiovascular } \\
\text { diseases }\end{array}$ \\
\hline $\begin{array}{l}\text { Belgium } \\
\text { Denmark } \\
\text { France } \\
\text { Germany (FRG) } \\
\text { Greece } \\
\text { Ireland } \\
\text { Italy } \\
\text { Luxembourg } \\
\text { Netherlands } \\
\text { Portugal } \\
\text { Spain } \\
\text { United Kingdom }\end{array}$ & $\begin{array}{r}11800 \\
13300 \\
12800 \\
13300 \\
6400 \\
7500 \\
12300 \\
14700 \\
12300 \\
6300 \\
8700 \\
12300\end{array}$ & $\begin{array}{l}76 \\
75 \\
77 \\
75 \\
77 \\
74 \\
76 \\
75 \\
77 \\
75 \\
77 \\
76\end{array}$ & $\begin{array}{l}879 \\
866 \\
715 \\
806 \\
765 \\
965 \\
770 \\
903 \\
748 \\
862 \\
755 \\
850\end{array}$ & $\begin{array}{l}224 \\
235 \\
205 \\
208 \\
160 \\
224 \\
209 \\
218 \\
223 \\
158 \\
168 \\
223\end{array}$ & $\begin{array}{l}342 \\
365 \\
224 \\
372 \\
376 \\
456 \\
324 \\
412 \\
302 \\
360 \\
323 \\
378\end{array}$ \\
\hline EC & 11800 & 76 & 789 & 204 & 331 \\
\hline
\end{tabular}

Department of Public Health,

Erasmus University, PO Box 1738

3000 DR Rotterdam,

The Netherlands

J P Mackenbach

C W N Looman

Correspondence to: Professor J P Mackenbach

Accepted for publication September 1993
* In US \$ per inhabitant, 1987. Purchasing power parities. Source: reference 11

† In years, 1989. Source: reference 12 .

$\ddagger$ Directly standardised to the European standard population, per 100000 person-years, ca 1988. Source: reference 13.

Correlation coefficients between GDP and:

Life expectancy at birth: $r=-0.014$;

Age standardised mortality ratio, all causes: $r=-0.058$

Age standardised mortality ratio, neoplasms: $r=0 \cdot 732$

Age standardised mortality ratio, cardiovascular diseases: $r=-0 \cdot 243$. 
circumstances associated with high mortality which happen to be more prevalent in countries with a high GDP) have prevented the association between living standards and mortality to become evident. To investigate this, we studied mortality at the regional level across the EC. This enabled us to do multivariate analyses while retaining a close link with national level data. We collected published data on mortality, living standards, and potential confounders at the regional level, and analysed these using multiple regression methods. In the analysis, the association between living standards and mortality was measured before and after controlling for the potential confounders.

After this main part of the analysis, we also explored which of the living standards variables had the strongest independent association with mortality, and whether the strength of these associations is the same or not in all EC countries.

\section{Methods}

The data used in this analysis were extracted from various sources. The most recent regional mortality data were published in the second edition of the European Community Atlas of 'Avoidable Death'. ${ }^{14}$ This contains all cause standardised mortality ratios (SMRs) (all ages, both sexes) for a total number of 360 regions in the EC, covering the period 198084. These SMRs were calculated using the age and sex specific mortality rates for the entire EC as standard rates. Although the principle of using indirectly standardised mortality rates (such as SMRs) could be discussed from a theoretical point of view, in practice the differences with directly standardised rates are usually negligible, especially if (as in this case) the age distributions of the populations to be compared are not extremely different.

The only regional data on living standards which meet some basic criteria of comparability are available in a recent Eurostat publication. ${ }^{15}$ This publication covers a slightly more recent period than the mortality data (various years in the period 1985-88), and also uses a different regional subdivision (mostly at a higher level of aggregation). We thus had to assume that regional patterns of socioeconomic indicators did not change between 1980-84 and 1985-88 - an assumption which is likely to be valid given the time scale at which processes of socioeconomic differentiation between regions operate. The second problem could be solved only by amalgamating regions as distinguished in the mortality atlas up to the level used in the Eurostat publication. To this end, weighted averages of SMRs were calculated, using the regional population sizes as weights. We also omitted all overseas departments (Ceuta y Melilla, Canary Islands, the French Départements d'Outre Mer (DOM), the Azores, Madeira) and ended up with a total number of 133 regions. The final number of regions per country was as follows: one for Ireland and Luxembourg, three for Denmark, four for
Portugal, five for Greece, nine for Belgium, 11 for the United Kingdom, 12 for the Netherlands, 16 for Spain, 18 for Italy, 22 for France, and 31 for Germany (then the Federal Republic of Germany). At this level of aggregation, the $95 \%$ confidence intervals of most SMRs were very narrow $( \pm 1-3 \%)$.

The following indicators of living standards were chosen: gross domestic product (per capita, converted to ecus using purchasing power parities, and expressed in indices which relate to the EC average, with the latter set to 100 ), car access (private cars per 1000 population) and unemployment (unemployed men per 100 men in the active population). These indicators cover different aspects of living standards. Gross domestic product is a macro variable which measures the economic output of a region; car access more directly reflects levels of spendable income; and unemployment rates are indicative of the existence and size of groups with socioeconomic disadvantage.

Mortality levels are determined by many more factors than living standards alone. We do not refer here to more "proximal" determinants such as cigarette smoking, which may be an intermediary factor between living standards and mortality, but to other factors at the same "distal" level of explanation, such as sociocultural factors. The Eurostat publication cited above ${ }^{15}$ contains information on three potential confounders of the relationship between living standards and mortality: population density (inhabitants per $\mathrm{km}^{2}$ ), agricultural employment (percentage of those employed who are active in the agricultural sector) and industrial employment (percentage of those employed who are active in the industrial sector). All three are associated with the level of socioeconomic development of a region, and have independent effects on mortality through more specific behavioural and environmental factors, ${ }^{16-18}$ which suggests that they may be confounders of the living standards-mortality relationship.

Table 2 shows the correlation between the independent variables included in the analysis. GDP and car access are both positively associated with population density and industrial employment, and negatively associated with agricultural employment. The latter variables are also associated with mortality (results not shown): population density and industrial employment are positively associated with mortality, whereas agricultural employment is negatively associated with mortality. This clearly supports the idea that population density, industrial employment, and agricultural employment, if not controlled for, will confound the living standards-mortality relationship. Table 2 also shows that the correlations are all below levels (that is, 0.70 ) which might introduce multicollinearity in the analysis.

Because these three variables cannot be expected to remove all confounding, we also estimated the effect of living standards controlling for "country", using a set of dummy variables (with 12 countries and Belgium set to zero, 11 dummy variables had to be created). 
Table 2 Correlations between the independent variables (133 EC regions)

\begin{tabular}{|c|c|c|c|c|c|c|}
\hline \multirow[b]{2}{*}{ Variable } & \multicolumn{6}{|c|}{ Product moment correlation coefficients } \\
\hline & $G D P$ & Cars & Unemployment & $\begin{array}{l}\text { Population } \\
\text { density }\end{array}$ & $\begin{array}{l}\text { Agricultural } \\
\text { employment }\end{array}$ & $\begin{array}{l}\text { Industrial } \\
\text { employment }\end{array}$ \\
\hline $\begin{array}{l}\text { GDP } \\
\text { Cars } \\
\text { Unemployment } \\
\text { Population density } \\
\text { Agricultural employment } \\
\text { Industrial employment }\end{array}$ & 1.00 & $\begin{array}{l}0.62 \\
1.00\end{array}$ & $\begin{array}{r}-0.22 \\
-0.41 \\
1.00\end{array}$ & $\begin{array}{r}0.40 \\
0.10 \\
-0.01 \\
1.00\end{array}$ & $\begin{array}{r}-0.49 \\
-0.59 \\
0.12 \\
-0.33 \\
1.00\end{array}$ & $\begin{array}{r}0.40 \\
0.46 \\
-0 \cdot 21 \\
0.05 \\
-0.39 \\
1.00\end{array}$ \\
\hline
\end{tabular}

For definition of variables, see methods section. GDP = gross domestic product.

We assumed that this would remove the effect of country specific factors such as dietary habits.

The analyses involved fitting a series of ordinary least squares regression models, with $\ln S M R$ as the dependent variable and using the GLIM package. ${ }^{19}$ For each of the three living standards variables, a series of four regression models was fitted:

Model 1: one living standard variable only;

Model 2: as model 1, plus three potential confounders (population density, agricultural employment, industrial employment); Model 3: as model 2, plus country dummies; Model 4: as model 3, plus the other two living standards variables.

In model 1 , the association between living standards and mortality is measured without any control for potential confounders. A comparison with the results of models 2 and 3 exposes the effect of controlling for confounding. With model 4 it can be seen which of the three living standards variables has the strongest independent association with mortality.

In a final step of the analysis, we explored whether the association between living stand- ards and mortality is the same in all countries. To this end, interaction terms between living standards variables and the country dummies were added to models of type 3 . A significance test for the introduction of these variables reached conventional levels of statistical significance $(p<0.05)$ in all three cases (that is, for GDP, car access, and unemployment).

\section{Results}

Tables 3 and 4 provide some illustrative data on regional mortality patterns in the EC. The highest mortality rates are found in Ireland and the northern parts of the United Kingdom, a northern Portuguese region, southern Belgium and Luxembourg, and West Berlin. The living standards in most of these regions are below the EC average: GDP and car access are relatively low, and unemployment rates are relatively high. The exceptions are West Berlin and Luxembourg.

Surprisingly, many of the regions with the lowest mortality also have unfavourable living standards (table 4). The lowest mortality rates in the EC are found in a region of The Netherlands (Zuidelijke IJsselmeerpolders, an area which was recently claimed from the waters of

Table 3 The 10 regions with the highest mortality rates in the European Community, 1980-84

\begin{tabular}{|c|c|c|c|c|c|}
\hline Region & Country & $\begin{array}{l}S M R \\
1980-84\end{array}$ & $\begin{array}{l}\text { GDP } \\
1985\end{array}$ & $\begin{array}{l}\text { Cars } \\
1985\end{array}$ & $\begin{array}{l}\text { Unemployment } \\
1988\end{array}$ \\
\hline Ireland & Ireland & 122 & 65 & 202 & $17 \cdot 4$ \\
\hline Norte & Portugal & 121 & 41 & 76 & $3 \cdot 3$ \\
\hline Namur & Belgium & 119 & 79 & 325 & $9 \cdot 6$ \\
\hline Berlin (W) & Germany & 119 & 128 & 344 & $7 \cdot 6$ \\
\hline Scotland & United Kingdom & 119 & 98 & 244 & $13 \cdot 6$ \\
\hline Northern Ireland & United Kingdom & 119 & 80 & 265 & $19 \cdot 3$ \\
\hline Liège & Belgium & 118 & 97 & 341 & 9.5 \\
\hline Hainaut & Belgium & 117 & 78 & 312 & $12 \cdot 3$ \\
\hline Luxembourg & Luxembourg & 116 & 124 & 414 & $1 \cdot 7$ \\
\hline North & United Kingdom & 116 & 92 & 249 & $14 \cdot 3$ \\
\hline EC & - & 100 & 100 & 342 & $8 \cdot 3$ \\
\hline
\end{tabular}

For definition of variables, see methods section. $\mathrm{SMR}=$ standardised mortality ratio, GDP = gross domestic product.

Table 4 The 10 regions with the lowest mortality rates in the European Community, 1980-84

\begin{tabular}{|c|c|c|c|c|c|}
\hline Region & Country & $\begin{array}{l}S M R \\
1980-84\end{array}$ & $\begin{array}{l}G D P \\
1985\end{array}$ & $\begin{array}{l}\text { Cars } \\
1985\end{array}$ & $\begin{array}{l}\text { Unemployment } \\
1988\end{array}$ \\
\hline \multicolumn{6}{|l|}{ Zuidelijke } \\
\hline IJssel-meerpolders & Netherlands & 76 & 65 & 350 & 6.9 \\
\hline Castilla-Leon & Spain & 80 & 72 & 204 & $13 \cdot 7$ \\
\hline Aragon & Spain & 81 & 80 & 222 & $8 \cdot 3$ \\
\hline Madrid & Spain & 82 & 83 & 272 & $12 \cdot 9$ \\
\hline Cataluña & Spain & 83 & 82 & 277 & $14 \cdot 1$ \\
\hline Crete & Greece & 84 & 55 & 84 & 1.8 \\
\hline Poitou-Charentes & France & 84 & 90 & 438 & $7 \cdot 8$ \\
\hline Midi-Pyrénees & France & 85 & 91 & 435 & 6.5 \\
\hline Ile de France & France & 86 & 165 & 358 & $7 \cdot 5$ \\
\hline Centre & France & 86 & 104 & 415 & $6 \cdot 8$ \\
\hline EC & - & 100 & 100 & 342 & $8 \cdot 3$ \\
\hline
\end{tabular}

For definition of variables, see methods section. $\mathrm{SMR}=$ standardised mortality ratio; $\mathrm{DGP}=$ gross domestic product. 
the former Zuiderzee) and in regions in Spain, Greece, and France. These Spanish and Greek regions, in particular, are clearly poorer than the EC average.

The results of the regression analysis are presented in table 5. Regression coefficients for the effect of each of the three living standards variables on mortality are shown, obtained with various regression models. If no potential confounders are included in the regression model, none of the associations between living standards and mortality is statistically significant, and the signs even suggest slightly higher mortality at higher living standards.

These univariate results are, however, seriously confounded. This is shown by a comparison with the coefficients obtained in regression models controlling for population density, agricultural employment, and industrial employment; and especially with those obtained in models which in addition control for "country". The signs of the coefficients reverse, implying higher mortality at lower living standards. Also, the coefficients for car access and unemployment rates reach conventional levels of statistical significance.

The final row of table 5 gives the results of a regression model which contains all three indicators of living standards as well as all control variables (including country dummy variables). It is only unemployment which seems to have mortality affects independent of those of other living standards variables.

Although some of the associations are statistically significant, none are very strong. The regression coefficient for the strongest association, that between unemployment and mortality, is 0.00804 (table 5). This implies that each additional per cent in unemployment is associated with a rise of the SMR by a factor of $\mathrm{e}^{0.00804}=1 \cdot 0081$, or by $0.81 \%$. On the basis of the same coefficient, the mortality in the region with the highest unemployment rate of the EC (Andalucia: 25.9\%) is expected to be $\mathrm{e}^{24.2} * 0.00804=1.21$ times or $21 \%$ higher than that in the region with the lowest unemployment rate (Luxembourg: $1 \cdot 7 \%$ ).

Although the effect of living standards seems to be present across the EC, an important question is whether it is the same in all countries. An analysis of the interaction between living standards variables and country showed that it is not. Table 6 shows the variation in the effect of living standards on mortality between the five largest EC countries. The main exception to the general rule of higher mortality at lower living standards is Italy: there is no association between living standards and mortality in this country (controlling for population density, industrial employment, and agricultural employment). In the other countries the patterns are roughly as documented for the EC as a whole, although there is striking variation in the strength of the associations (those in the United Kingdom are strongest), as well as in the relative importance of each of the three indicators (for example, car access is important in France and the United Kingdom, but not in Germany, Spain, and Italy).

\section{Discussion}

It has frequently been shown that above a certain level of economic development, the association between countries' living standards

Table 5 Results of the regression analysis of mortality on indicators of living standards (133 EC regions)

\begin{tabular}{|c|c|c|c|c|}
\hline \multirow[b]{2}{*}{ Model } & \multirow[b]{2}{*}{ Control variables } & \multicolumn{3}{|c|}{ Regression coefficient* } \\
\hline & & $G D P$ & Cars & Unemployment \\
\hline 1 & - & 0.00019 & 0.00003 & -0.00101 \\
\hline 2 & $\begin{array}{l}\text { Population density } \\
\text { agricultural employment } \\
\text { industrial employment }\end{array}$ & -0.00072 & -0.00020 & 0.00056 \\
\hline $\begin{array}{l}3 \\
4\end{array}$ & $\begin{array}{l}\text { As } 2+\text { country dummies } \\
\text { As } 3+\text { other } 2 \text { living } \\
\text { standard variables }\end{array}$ & $\begin{array}{l}-0.00048 \\
-0.00021\end{array}$ & $\begin{array}{l}-0.00050 \dagger \\
-0.00011\end{array}$ & $\begin{array}{l}0.00804{ }^{\dagger} \\
0.00691 \dagger\end{array}$ \\
\hline
\end{tabular}

For definition of variables, see methods section.

* Interpretation of the coefficients $(\beta)$ : each extra unit of the independent variable ( $1 \%$ extra GNP per capita, one extra private car per 1000 population, one extra unemployed man per 100 men in the active population) goes together with a rise of the SMR by a factor $\mathrm{e}^{\beta}$. See penultimate paragraph of the results section for an illustration.

$+p<0.05$.

Table 6 Analysis of interaction: estimates of regression coefficients for the five largest EC countries (controlling for population density, agricultural employment, and industrial employment

\begin{tabular}{llll}
\hline $\begin{array}{l}\text { Country } \\
\text { (no of regions) }\end{array}$ & \multicolumn{2}{l}{ Regression coefficient } \\
\cline { 2 - 3 } & GDP & Cars & Unemployment \\
\hline $\begin{array}{l}\text { Germany (FRG) } \\
(n=31)\end{array}$ & $-0.00154^{\dagger}$ & -0.00082 & $0.01160{ }^{\dagger}$ \\
$\begin{array}{l}\text { Spain } \\
(n=16)\end{array}$ & $-0.00278^{\dagger}$ & -0.00001 & $0.00614^{\dagger}$ \\
$\begin{array}{l}\text { France } \\
(n=22)\end{array}$ & -0.00135 & $-0.00184 \dagger$ & 0.00778 \\
$\begin{array}{l}\text { Italy } \\
(n=18)\end{array}$ & 0.00007 & 0.00004 & 0.00082 \\
$\begin{array}{l}\text { United Kingdom } \\
(n=11)\end{array}$ & $-0.00511^{\dagger}$ & $-0.00160 \dagger$ & $0.01738{ }^{\dagger}$ \\
$\begin{array}{l}\text { EC } \\
(n=133)\end{array}$ & -0.00048 & $-0.00050^{\dagger}$ & $0.00804^{\dagger}$ \\
\hline
\end{tabular}

For definition of variables, see methods section

* Interpretation of the coefficients $(\beta)$ : each extra unit of the independent variable $(1 \%$ extra GNP per capita, one extra private car per 1000 population, one extra unemployed man per 100 men in the active population) goes together with a rise of the SMR by a factor $\mathrm{e}^{\beta}$. See penultimate paragraph of the results section for an illustration.

$+p<0.05$. 
and mortality levels becomes weaker. For developing countries, life expectancy increases steeply with increasing GDP per capita, but for developed countries the curve is much flatter. ${ }^{20}$ This is probably due to two different mechanisms: an effect of diminishing returns at higher levels of spending on improvements in living circumstances, and the rise of so called "degenerative" or "western" diseases such as cardiovascular disease and neoplasms. ${ }^{2122}$

Within the EC, the lack of an association between living standards and mortality at country level (table 1) is one more example of these flattening curves. The cause specific data presented in table 1 suggest that for neoplasms the EC countries are still in a stage of rising mortality with an increase in living standards. For cardiovascular disease, on the other hand, the association has already reversed.

If associations are weak, control for confounding becomes relatively more important. The results of our analysis show that, after control for confounding variables, there is an association between living standards and mortality in the EC. It seems that the mortality increasing effects of urbanisation and industrialisation have obscured the mortality lowering effects of high living standards. The most important step, however, was the introduction of the control variable "country". In our analysis living standards variables had clear effects on mortality only after allowing for different mortality levels in different countries.

Now what could this "confounding by country" be? As was mentioned in the methods section, the introduction of country dummies into the regression equation was intended to remove the effect of country specific factors such as dietary habits. It is well known that not all developed countries have gone through the "epidemiologic transition" from infections to "western" diseases in the same way. For example, in some countries, especially in western and northern Europe as well as in northern America, the rise of ischaemic heart disease has been much more pronounced than that in the Mediterranean countries, ${ }^{23}$ perhaps because of the regular consumption of red wine and olive oil in the latter. $^{2425}$

The case of Italy may help to increase further our understanding of this phenomenon. Associations between socioeconomic indicators and mortality at the regional level have been documented before for many separate EC countries, such as France, ${ }^{26}$ Germany, ${ }^{27}$ the Netherlands, ${ }^{2829}$ Spain, ${ }^{30}$ and the United Kingdom. ${ }^{31}{ }^{32}$ Our analysis has confirmed that it is indeed a community wide phenomenon, but that there is one exception - Italy.

In Italy, mortality is higher in the north than in the south. ${ }^{33}$ Without control for population density, agricultural employment, and industrial employment, the association between living standards and mortality is even clearly positive (results not shown). As table 5 shows, with such control there is no association at all. Whereas infant mortality and mortality from infectious diseases are still slightly higher in the south, mortality from "western" diseases (cardiovascular, neoplasms) is considerably higher in the north. ${ }^{34}$ In Italy, the western and northern European mortality regime and the Mediterranean mortality regime coexist. The lack of an association between living standards and mortality as it was found EC wide (before controlling for "country"), is therefore reproduced within Italy.

The variable that has the strongest independent association with mortality is unemployment. Currently, there is no scientific consensus on the effect of unemployment on mortality. ${ }^{35}$ Longitudinal studies consistently show higher mortality in the unemployed ${ }^{36-38}$ but the main problem with these data is that selection factors may be at work. The unemployed may have been sick before unemployment, or may have characteristics predisposing to both unemployment and premature death. ${ }^{35}$ On the other hand, studies of unemployment and mortality at the regional level, which can less easily be biased by selection factors but have other methodological shortcomings, have produced inconsistent results. ${ }^{39}$ Perhaps our results can be interpreted as further evidence for an effect of unemployment on mortality, although aggregate unemployment rates are associated with many other characteristics linked to deprivation, which were not controlled for in the analysis.

The fact that unemployment, the variable most closely related to (relative) deprivation, has the strongest association with mortality in this analysis also supports previous reports on the relationship between income distribution and mortality at the national level. ${ }^{40}$ More generally speaking, the distribution of income (and other aspects of living standards) within a country may be more important for the level of mortality than the distribution across countries.

The Maastricht Treaty intends to give the EC a bigger say on health policy. ${ }^{41}$ It is to be welcomed that public health is gradually becoming more important to the EC. It can be argued that one of the first things to be done is to assess the health impacts of EC policies in "other" areas, and to see whether these could be modified to serve better the health interests of the European citizens. The EC agricultural policy, with its subsidies to tobacco producers, is a case in point. ${ }^{42}$ Another issue is that of the creation of a single European market: this has been decided without any insight into the potential effects on health and health care systems. ${ }^{43}$

In order to reach a fair judgement on the health impacts of EC policies, however, one should also pay attention to the potential health benefits of rising living standards, the primary goal of many EC policies. Our study provides some evidence on these benefits. If higher living standards are currently associated with lower mortality, and if one assumes that this association reflects a causal relationship, it is reasonable to expect that a rise in living standards contributes to a reduction in mortality as well. 
The results of our study do suggest that a fair judgement of the health impacts of EC policies should take into account the potential beneficial effects of rising living standards on life expectancy. However, as was shown by the calculations for unemployment presented above, at the current level of economic development these effects are not likely to be large.

1 Whitehead M. The health divide, 2nd ed. In: Inequalities in health. Harmondsworth: Penguin, 1992.

2 Illsley R, Svensson P-G (eds). Social inequities in health. Soc Sci Med 1990;31:223-240.

3 Anderson O. Occupational mortality in the Nordic Countries 1971-1980. Statistical reports of the Nordic countries no 49. Copenhagen: Danmarks Statistik, 1988.

4 Neuman G von, Liedermann A. Mortalität und Sozialschicht. Bundesgesundheitsblatt 1981;24:173-81.

5 Mackenbach JP. Socio-economic health differences in the Netherlands: a review of recent empirical findings. Soc Sci Med 1992;34:213-26.

6 Fox AJ, Goldblatt PO. Longitudinal study; socio-demographic mortality differentials. OPCS Series LS no 1. London: HMSO, 1982.

7 Nolan B. Socio-economic mortality differentials in Ireland. Economic and Social Review 1990;21:193-208.

8 Desplanques G. La mortalité des adultes; résultats de deux études longitudinales (période 1955-1980). Paris: INSEE, 1984.

9 Regidor E, Gonzalez J. Social inequality and mortality in Spain (in Spanish). Rev Sanid Hig Publica /Madr 1989;63:107-116.

10 Pagnanelli F. Italie: les differences de mortalité selon certains facteurs socio-économiques. In: Proceedings of the Sth meeting of the UN WHO CICRED network on socioeconomic differential mortality in industrialized countries. Paris: CICRED, 1991 .

11 Organization for Economic Co-operation and Development. Health care systems in transition. OECD Social Policy Studies no 7. Paris: OECD, 1990

12 World Bank. World Development Report 1991: the challenge of development. Oxford: Oxford University Press, 1991.

13 World Health Organization. World Health Statistics Annual 1990. Geneva: World Health Organization, 1991.

14 EC Working Group on Health Services and 'Avoidable Deaths'. European Community atlas of 'avoidable death' 2nd ed, vol. 1. Oxford: Oxford University Press, 1991.

15 Eurostat. Regions; statistical yearbook 1989. Luxembourg. Statistical Office of the European Communities, 1990.

16 Kitagawa EM, Hauser PM. Differential mortality in the United States. Boston: Harvard University Press, 1973.

17 Lerner M, Stutz RN. Have we narrowed the gaps between the poor and the non-poor? Part II: mortality. Med Care 1977;15:620-35.

18 Fox AJ, Jones DR, Goldblatt PO. Mortality in England and Wales: socio-economic factors. Br Med Bull 1984;40:30914.

19 Baker RJ, Nelder JA. GLIM manual (release 3). Oxford: Numerical Algorithms Group, 1987.

20 Preston SH. The changing relation between mortality and level of economic development. Population Studies level of economic

21 Omran AR. The epidemiologic transition; a theory of the epidemiology of population change. Milb Mem Fund Wuart 1971;49:509-38.

22 Trowell HC, Burkitt DP. Western diseases: their emergence and prevention. London: Edward Arnold, 1981.

23 Uemura $K$, Pisa $Z$. Trends in cardiovascular disease mortality in industrialized countries since 1950. World Hith Stat Quart 1988;41:155-78.

24 Renaud S, Lorgezil $M$ de. Wine, alcohol, platelets, and the French paradox for coronary heart disease. Lancet 1992;339:1523-6.

25 Ulbricht TLV, Southgate DAT. Coronary heart disease: seven dietary factors. Lancet 1991;338:985-92.

26 Caselli G. Les causes de décès en France III. Un effor d'interprétation des différences géographiques. Population 1984;6:1011-44.

27 Kemper F-J, Thieme G. Regional disparities of mortality in the Federal Republic of Germany. Espace, Populations, Societes 1991;1:93-100.

28 Kunst AE, Looman CWN, Mackenbach JP. Socio-economic mortality differences in the Netherlands in 1950 1984: a regional study of cause-specific mortality. Soc Sci 1984: a regional study of

29 Mackenbach JP, Kunst AE, Looman CWN. Cultural and economic determinants of geographical mortality patterns in the Netherlands. $f$ Epidemiol Community Health 1991;45:231-7.

30 Higueras Arnal A. Mortalité et changement social en Espagne (1975-1988). Espace, Populations, Sociëtes 1991;1:143-50.

31 Charlton JRH, Hartley RM, Silver R, Holland WW. Geographical variation in mortality from conditions amenable to medical intervention in England and Wales. Lancet 1983;1:691-6.

32 Carstairs V, Morris R. Deprivation: explaining differences in mortality between Scotland and England and Wales. BMF 1989;299:886-9.

33 Meneghel G. La mortalite en Italie selon des facteurs socioéconomiques. Espace, Populations, Sociétés 1991;1:17380.

34 Papa O. Les disparités géographiques de la mortalité en Italic, 1951-1981. Espace, Populations, Sociétés 1991;1:165-71.

35 Valkonen T, Martikainen P. The association between unemployment and mortality: causation or selection? In Lopez AD, Caselli G, Valkonen T eds. Adult mortality in developed countries; from description to explanation. Oxford: Oxford University Press, 1993.

36 Moser K, Goldblatt P, Fox J, Jones D. Unemployment and mortality: In: Goldblatt P ed. Longitudinal study; mortality and social organization. Office of Population Censuses and Surveys. Series LS, no 6. London: Her Maisuses and Surveys. Series LS,

37 Martikainen P. Unemployment and mortality among Finnish men, 1981-1985. BMF 1990;301:407-11.

38 Iversen J, Anderson O, Andersen PK, Christofferson K, Keiding N. Unemployment and mortality in Denmark, 1970-1980. BMF 1987;295:879-84.

39 Charlton JRH, Bauer R, Thakore A, Silver R, Aristidou M. Unemployment and mortality: a small area analysis. $\mathcal{F}$ Epidemiol Community Health 1987;41:107-13.

40 Wilkinson RG. Income distribution and life expectancy. $B M F$ 1992;304:165-8.

41 Rogers A. European Community: health policy after Maastricht. Lancet 1992;339:171-2.

42 Townsend J. Tobacco and the European common agricultural policy; European gold kills. BMf 1991;303:1008-9.

43 Leidl R. How will the single European market affect health care? Good question. BMF 1991;303:1081-2. 